\title{
Evaluation of Some Chemical Composition of Pawpaw (Carica Papaya) Seeds under Normal Storage Ripening
}

\author{
G.O. Oyeleke ${ }^{1}$, A.D. Isola ${ }^{1}$, M.A. Salam ${ }^{1}$ and F.D. Ajao ${ }^{2}$ \\ ${ }^{1}$ Science Laboratory Technology Department, Osun State Polytechnic, Iree, Nigeria. \\ ${ }^{2}$ Food Science and Technology Department, Osun State Polytechnic, Iree, Nigeria.
}

\begin{abstract}
The physicochemical changes in pawpaw (Carica papaya) seeds during normal storage ripening stages (mature unripe, ripe and overripe) were investigated in terms of the proximate, mineral and antinutritional composition using standard analytical techniques. From the analysis, the \% proximate composition of mature unripe, ripe and overripe pawpaw seeds showed that it has moisture content $(5.00 \pm 0.01$, $10.00 \pm 0.02,10.00 \pm 0.02)$, ash content $(8.00 \pm 0.03,9.00 \pm 0.02,9.00 \pm 0.05)$, crude fibre (32.00 $\pm 0.01,35.00 \pm 0.01$, $35.00 \pm 0.00)$, fat $(26.00 \pm 0.03,27.00 \pm 0.05,26.00 \pm 0.01)$, crude protein $(5.90 \pm 0.04,6.00 \pm 0.03$ and $6.5 \pm 0.05)$ and carbohydrate $(23.10 \pm 0.05,13.00 \pm 0.01$ and $13.50 \pm 0.00)$. The elements determined in ppm include manganese $(36.81 \pm 0.01,35.10 \pm 0.01$ and $39.28 \pm 0.05)$, iron $(50.11 \pm 0.01,49.66 \pm 0.04$ and $53.48 \pm 0.07)$ and zinc $(18.17 \pm 0.05$, $15.99 \pm 0.01$ and $21.08 \pm 0.02)$ in mature unripe, ripe and overripe pawpaw seeds respectively. The antinutrients in $\mathrm{mg} / 100 \mathrm{~g}$ are phytate $(7.89 \pm 0.02,9.25 \pm 0.10$ and $6.54 \pm 0.30)$, saponin $(1.04 \pm 0.20,1.22 \pm 0.10$ and $1.07 \pm 0.40)$, oxalate $(0.32 \pm 0.00,0.25 \pm 0.01$ and $0.41 \pm 0.10)$, tannin $(0.15 \pm 0.02,0.10 \pm 0.01$ and $0.16 \pm 0.20)$ and trypsin inhibitor $(0.20 \pm 0.10,0.09 \pm 0.10$ and $0.14 \pm 0.20)$ in the samples. The results showed that the seeds at various stages of ripening are cheap source of minerals and fat to man and animal and could be utilized commercially.

Keywords: Physicochemical, changes, storage, ripening, mineral, fat, antinutrient.
\end{abstract}

\section{Introduction}

Fruits and vegetables are nutrient suppliers which have effects on several functions of man. Pawpaw (Carica papaya) belongs to the family caricaceae with over 22 species while only one member of the genus carica is cultivated as fruit tree.

According to Food and agriculture Organization [1], it is an invaluable plant that is prevalent throughout tropical Africa and Nigeria is the third largest producer globally. It is eaten because of its nutritional value and its medicinal properties. This also makes it to be of economic value. The fruit is rich in provitamin A, carotenoids, lycopene, vitamins, dietary minerals and dietary fibre [2,3]. The skin, pulp and seed contain varieties of phytochemicals including natural phenol and flavonoids which have antioxidant properties [4].

It was also reported that they may contain immunomodulary compounds that can cause growth and contains compounds that kill parasites [5]. Okeniyi et al.,[6], noticed that they are antihelminthic and antiamoebic in activities as well as anticancer and antidiabetic properties. This research work was carried out to determine the physicochemical changes in pawpaw seeds under normal storage ripening in order to expand its usages.

\subsection{Sample Collection}

\section{Materials and Methods} State, Nigeria.

The pawpaw (Carica papaya) fruits were collected from Iba town, Ifelodun Local Government of Osun

\subsection{Sample Preparation}

The matured fruits were separated into three parts, the first part (mature unripe), the other two parts were subjected to normal storage ripening (at room temperature) in the laboratory. The second sample was taken when the fruits became ripe while the third part was allowed to overripe. The samples were sliced opened using sterilized stainless steel laboratory knife and the seeds collected separately. The seeds were washed in distilled water, sun dried, grinded with a (Phillips Harris model) laboratory blender, passed through a $2 \mathrm{~mm}$ sieve and the powder stored in polythene bags ready for further analysis.

\subsection{Proximate Analysis}

The moisture content, dry matter, crude fibre, crude protein, ash and ether extract of the seeds of pawpaw (Carica papaya) were analyzed by the methods of AOAC, [7].

Carbohydrate content was determined by difference.

$\%$ Carbohydrate $=100-(\%$ Ash $+\%$ Fibre $+\%$ Moisture $+\%$ Protein $+\%$ Fat $)$ 


\subsection{Mineral Determination}

The micronutrients (zinc, iron and manganese) were all determined by spectrophotometric methods using Atomic Absorption Spectrophotometer [7].

\subsection{Antinutrient Determination}

Phytate content was determined using Onwuka [8] method while saponin, oxalate, tannins and trypsin inhibitor were determined using method of Pearson [9].

\subsection{Results}

\section{Results and Discussion}

Table 1: Proximate Analysis (\%) of Pawpaw Seeds under Normal Storage Ripening.

\begin{tabular}{lrrr}
\hline Parameters & \multicolumn{1}{c}{ A } & \multicolumn{1}{c}{ B } & \multicolumn{1}{c}{ C } \\
\hline Moisture & $5.00 \pm 0.01$ & $10.00 \pm 0.02$ & $10.00 \pm 0.02$ \\
Dry matter & $95.00 \pm 0.01$ & $90.00 \pm 0.04$ & $90.00 \pm 0.00$ \\
Ash & $8.00 \pm 0.03$ & $9.00 \pm 0.02$ & $9.00 \pm 0.05$ \\
Crude fibre & $32.00 \pm 0.01$ & $35.00 \pm 0.01$ & $35.00 \pm 0.00$ \\
Fat & $26.00 \pm 0.03$ & $27.00 \pm 0.05$ & $26.00 \pm 0.01$ \\
Crude protein & $5.90 \pm 0.04$ & $6.00 \pm 0.03$ & $6.50 \pm 0.05$ \\
Carbohydrate & $23.10 \pm 0.05$ & $13.00 \pm 0.01$ & $13.50 \pm 0.00$ \\
\hline
\end{tabular}

$\mathrm{n}=2$

A- mature unripe seed

B - ripe seed

B- overripe seed

Table 2: Microelements of Pawpaw Seeds (mg/kg)

\begin{tabular}{lccc}
\hline Elements & A & B & C \\
\hline Manganese $(\mathrm{Mn})$ & $36.81 \pm 0.01$ & $35.1 \pm 0.01$ & $39.28 \pm 0.05$ \\
Iron $(\mathrm{Fe})$ & $50.11 \pm 0.01$ & $49.66 \pm 0.04$ & $53.48 \pm 0.07$ \\
Zinc $(\mathrm{Zn})$ & $18.17 \pm 0.05$ & $15.99 \pm 0.01$ & $21.08 \pm 0.02$ \\
\hline
\end{tabular}

$\mathrm{n}=2$

Table 3: Antinutrient Composition of Pawpaw Seed (mg/100g)

\begin{tabular}{lccc}
\hline Parameter & $\mathbf{A}$ & $\mathbf{B}$ & $\mathbf{C}$ \\
\hline Phytate & $7.89 \pm 0.01$ & $9.25 \pm 0.03$ & $6.54 \pm 0.01$ \\
Saponin & $1.04 \pm 0.02$ & $1.22 \pm 0.05$ & $1.07 \pm 0.05$ \\
Oxalate & $0.32 \pm 0.03$ & $0.25 \pm 0.02$ & $0.41 \pm 0.02$ \\
Tannin & $0.15 \pm 0.05$ & $0.10 \pm 0.00$ & $0.16 \pm 0.01$ \\
Trypsin inhibitor & $0.12 \pm 0.02$ & $0.09 \pm 0.02$ & $0.14 \pm 0.03$ \\
\hline
\end{tabular}

\subsection{Discussion}

The proximate compositions of pawpaw (Carica papaya) seeds from mature unripe, ripe and overripe fruits are presented in Table 1. The moisture content (\%) of matured unripe seed was found to be $5.00 \pm 0.01$ which increased to $10.00 \%$ in the ripe and overripe stages. There is deviation in moisture content when compared to $7.20 \pm 0.00 \%$ reported for the seed by Puangsri et al., [10]. Low moisture content of the matured unripe seed means it can be stored for a longer period than ripe and overripe ones because of its better resistance to microbial attack [11].

Crude fibre content increases from $32.00 \pm 0.01 \%$ in mature unripe to $35.00 \pm 0.01 \%$ for both ripe and overripe seeds. The value of $19.1 \pm 0.2 \%$ reported by Puangsri et al., [10] is low compared to those found at the various stages determined. The fibre content is an indication that it contains a portion of cellulose, hemicellulose and lignin. Its high content makes it potential raw material in feed formulation since it causes good bowel movement and aid absorption [8]. It also slows the release of glucose into blood stream.

The ash content in mature unripe stage was $8.00 \%$ and increases to $9.00 \%$ in ripe and overripe stages. The $8.9 \%$ ash content for the samples was in line $8.2 \pm 0.1 \%$ as determined by Puangsri et al., [10]. Ash content indicates level of mineral content of a material. The high level obtained showed that they might not be useful as a livestock feed because the value is higher than $1.5-2.5 \%$ suggested for livestock feed. 
The ether extract (fat) increases from $26.00 \%$ in matured unripe to $27.00 \%$ in ripe and later decreased in the overripe sample to $26.00 \%$. This might be due to microbial activities that make use of fat as source of energy in the ripening process. Fat content of a sample is important because it determines its palatability. Pawpaw seeds at different ripening stages can therefore be good sources of fat to the populace.

The protein level of 5.90\%, 6.00\% and 6.50\% in matured unripe, ripe and overripe stages respectively showed the gradual increase as ripening increases because of microbial activities in the ripening stages especially in the overripe sample. The low protein content in the samples could be as a result of increase in the sugar content and therefore needs to be supplemented from other sources because protein is useful in the repairing of the worn out tissues and building up of new ones [12]. High protein content improves organoleptic properties of food materials.

Carbohydrate levels decreased from $23.10 \%$ in mature unripe to $13.00 \%$ in ripe mature seed and later increases to $13.50 \%$. The decrease in carbohydrate content may be because of the enzymes activities that use carbohydrate as the source of energy during ripening process. The later increase may be due to conversion of fat to carbohydrate in the overripe stage and this may account for the sweetness of the sample at this stage.

Table 2 showed the mineral element composition. Manganese $(\mathrm{Mn})$ and iron $(\mathrm{Fe})$ contents were found to be highest in overripe stage and lowest in ripe seed. Mn plays structural role in chloroplast system, DNA and RNA and maybe responsible for colour, taste and smell. It is a cofactor fatty acid synthesis [13], iron (Fe) content reduces from $50.11 \mathrm{ppm}$ in matured unripe to $49.66 \mathrm{ppm}$ in ripe and then increases to 53.48 in overripe seed. Iron is required for the synthesis of hemoglobin and myoglobin, which are oxygen carriers in the blood and muscle. The values obtained from the various stages are above the daily requirement for men and non-menstruating and pregnant women of $18 \mathrm{mg} / \mathrm{day}$. Zinc ( $\mathrm{Zn})$ was found to be highest in the overripe seed and lowest in the ripe stage. This may be due to some biological changes that have taken place during the ripening process. $\mathrm{Zn}$ is essential, in minute amount for growth, tissue repair, normal function of immune system and obligatory excretion [14].

The determination of the amount antinutrients in the samples is necessary because their reseearch can reduce essential nutrients bioavailability. Some of these antinutrients have been found to have protection against some diseases. From table 3, ripening was found to decrease the levels of phytate, saponin, oxalate and tannin while the level of trypsin inhibitors increased. Phytate level increases from $7.89 \pm 0.01 \%$ in unripe to $9.25 \pm 0.03 \%$ in ripe and then reduces to $6.54 \pm 0.01 \%$ in overripe. Phytate has strong binding capacity and forms insoluble complexes with multivalent cations, including $\mathrm{Ca}, \mathrm{Mg}, \mathrm{Fe}$ and $\mathrm{Zn}$, and render them biologically unavailable. Saponin level was found to be $1.04 \pm 0.02 \%, 1.22 \pm 0.05 \%$ and $1.07 \pm 0.05 \%$ in matured unripe, ripe and overripe stages respectively. Saponins are glycoside component referred to as natural detergent because of their foaming ability and possess both beneficial and deleterious property depending on concentration in samples. It has anticarcinogenic properties, immune modulation activities and regulation of cell proliferation as well as cholesterol lowering activity. The results showed that ripening could also be a way of reducing antinutrients in food samples.

Oxalate content reduced from $0.32 \pm 0.03 \%$ in mature unripe to $0.25 \pm 0.02 \%$ in ripe and then increase to $0.21 \pm 0.02 \%$ in overripe sample. Generally, small amounts of oxalate may occur in many vegetables and fruits but do not pose nutritional problems.

Tannin content was found to be $0.15 \pm 0.05 \%, 0.10 \pm 0.00 \%$ and $0.16 \pm 0.01 \%$ for matured unripe, ripe and overripe seeds respectively. Tannin is an antinutrient that inhibits activity of digestive enzymes. The lower values obtained for tannin is very important because tannic acid above $10 \%$ of total dry weight affects overall nutritional potential of food material. Importantly, tannin can be used in treatment of skin eruption due to their astringent properties.

Trypsin inhibitor have $0.12 \pm 0.02 \%, 0.90 \pm 0.02 \%$ and $0.14 \pm 0.01 \%$ values for mature unripe, ripe and overripe samples respectively showing an increase in values as ripening progresses.

\section{Conclusion}

It can be concluded from the research work that Pawpaw seeds (especially the overripe sample) are good sources of protein, energy, nutritive minerals coupled with low antinutrient values which could make it useful as alternative source of raw material in feed formulation.

\section{References}

[1] Food and Agricultural Organisation (FAO), United Nations statistics (2008), online Website http://faostat.fao.org.

[2] L.P. Bari, N. Hassen, M.E. Absar, M.I.I.E. Haque, M.M. Khuda, S.K. Pervin and M.I. Hossain, Nutritional Analysis of Two Varieties of Papaya (Carica papaya) at Different Maturation Stages. Pak. J. Biol. Sci., 9 (2006):137-140.

[3] F.O. Adetuyi, S.O. Akindwo, S.O. Omosuli and A. Lola, Anti-nutrient and Anti-Oxidant Quality of Waxed and Unwaxed Pawpaw Carica papaya fruit stored at Different Temperatures. Afri.J. Biotech. 7: (2008):2920-2924.

[4] K. Zhou, H.Wang, W. Mei, X. Li, Y. Luo and H. Dai, Antioxidant Activity of Papaya Seed Extracts. Molecules. 16 (8) (2011):6179-92. 
[5] P.J. Wabo, J.D. Ngankam Ntemah, C.F. Bilong Bilong, M. Mbida, A Comparative study of the Ovicidal and Larvicidal activities of Aqueous and Ethanolic Extracts of Pawpaw Seeds Carica papaya (Caricaceae) on Heligmosomoides bakeri. Asian Pac. J. Trop. Med. 4(6) (2011):447-450.

[6] J.A. Okeniyi, T.A. Ogunlesi, O.A. Oyelami and L.A. Adeyemi, Effectiveness of Dried Carica papaya Seeds against Human Intestinal Parasites: A Pilot Study. J. Med. Food. 10(1) (2007):194-6.

[7] AOAC, Official Methods of Analysis of the Association of Official Analytical Chemists. 17 ${ }^{\text {th }}$ Ed. (2005). Association of Official Analytical Chemist, Washington DC, USA.

[8] G.I. Onwuka, Food Analysis and Instrumentation Theory and Practice. Lagos, Napthali Prints. (2005) Pp 142-143.

[9] D. Pearson, The Chemical Analysis of Foods. Church-Hill Livingstone, Edinburg, London, UK. (1976) Pp 95-96.

[10] T. Puangsri, S.M. Abdulkarim and H.M. Ghazali, Properties of Carica papaya L.(papaya) Seed Oil following Extractions Using Solvent and Aqueous Enzymatic Methods. Journal of Food Lipids. 12 (2005):62-76.

[11] G.O. Oyeleke, Evaluation of Nutrient and Antinutrient Compositions of Hibiscus Sabdariffa Seed Flour. Int. J. of Food Sci. and Tech. 1(1) (2009):31-35.

[12] A.J Achu, Protein Wisely of some Nigerian Food Stuff Biological Evaluation of Protein.Quality J. Sci., Food \& Agric., 3(2) (2005):283-285.

[13] F.A. Ayaz, H.G. Robert, M. Milson, H.S.Huang, L.T. Chuang, S. Carlos and H. Ayaz, Nutrient Content of Kale (Brassica oleraceae L. Varecephata DC). Food Chem. 96 (2006):5572-79.

[14] L.G. Hassan, N.A. Sani, S.M. Dangoggo and M.J. Ladan, Nutritional Value of Bottle Gourd (Lagenaria siceraria) Seed. Global J. of Pure and Appl. Sci.14 (3) (2008):301-306. 